\title{
DOUBLE PREDESTINATION VIEW BY JOHN CALVIN, IN HIS COMMENTARIES AND INSTITUTIO BOOK
}

\author{
Elisabeth Sulastri \\ The Evangelical Theological Seminary of Indonesia - Yogyakarta \\ E-mail: elizabetsulastri10@gmail.com
}

\begin{abstract}
This article discusses the teaching view of John Calvin about Double Predestination. Any Bible verses that are the basis of explaining this teaching. The explanation of these verses can be the basis for understanding the teaching of John Calvin about Double Predestination. There are tree topic discussions in this article, First Double Predestination View by John Calvin, second in His Commentaries, and third institution book. May this article provide new insight and enlightenment for every reader.
\end{abstract}

Keywords: Double, Predestination, View, Commentaries, Institutio Book

\section{INTRODUCTION}

Firstly, I will discuss crucial verses which used by John Calvin to support his doctrine of double predestination. There are seven elective verses which will be described in this thesis from Old Testament until New Testament.

These seven verses are verses which were used by Calvin to support his doctrine of double predestination. I will not only provide those verses but also Calvin's interpretation about them. After describing Calvin commentaries about those verses, I

\footnotetext{
${ }^{1}$ The LORD made everything for its own purpose, even the wicked He made for the day of calamity.
}

will explain the main teaching of double predestination in Institutio Book.

\section{In His Commentaries}

According to Calvin, Proverbs $16: 4^{1}$ is clear enough states that God actually sets and predestines everything either good or wicked people. Based on this Proverbs, God has already prepared the day of calamity for the wicked. He doesn't allow bad things for bad people but He predestines the wicked life and destiny. Therefore, Calvin concluded that God makes everything either good or bad. This understanding supports the 
idea that God is sovereign over anything including evil and $\mathrm{He}$ has predestined the wicked for the day of calamity "eternal death". ${ }^{2}$

In addition to Proverbs $16: 4$, the doctrine of double predestination also is shown in Malachi book in Old Testament. Calvin adduced that Malachi $1: 2$ is one of the strongest evidence that God has predestined human future either to be saved or perished beforehand (before Adam and Eve were created). Holy Scripture states that "I have loved you," says the LORD. But you say, "How hast Thou loved us?" "Was not Esau Jacob's brother?" declares the LORD. "Yet I have loved Jacob (Mal 1:2 NAS).

This verse surprises Calvin about God's love to Jacob. Calvin explained that his verse talks about God's rebuke to His wicked people because they didn't know how to grateful to Him. They didn't honor and fear Yahweh, God of Israel because they kept questioning God's love. ${ }^{3}$

The object of Malachi was in reminding the Jews that they were loved and chosen by God; it was, that he might the more amplify their ingratitude for having

${ }^{2}$ John Calvin, Institute of Christian Religions, 206. ${ }^{3} \mathrm{http} / / /$ www.iclnet.org/pub/resources/text/m.sion/cv mal-01.htm rendered such an unworthy reward for so great a favor of God: as he had preferred them to all other nations, he had justly bound them to perpetual obedience. There is here mentioned a special favor - that the Lord took to himself the seed of Abraham, as it is said in the song of Moses that all nations are God's, but that he had cast his line to set apart Israel for himself (Deuteronomy 32:9). ${ }^{4}$

Though then the whole world was under God's government, it was yet his will to choose one family. If the cause be enquired, it is not to be found in men; for all were created from the earth, and souls were implanted in their bodies created from nothing.

Since it was so, we see that the difference arose from the fountain of gratuitous favor - that God preferred one race to the rest; and Moses often repeats this - that the Jews were not chosen because they were more excellent than other nations, but because God gratuitously loved their fathers. (Deuteronomy 7:7). By love he means gratuitous favor. Malachi then does not consider here that the Jews had been chosen before other nations on the ground of their own merit; for if he granted this, they might have objected and said - "Why

${ }^{4}$ http://www.ccel.org/ccel/calvin/calcom30.pdf 
dost thou remind us that God has favored us more than other nations, since he deemed us worthy, and rewarded our merit?" But the Prophet takes it as admitted, according to what I have already said, that the Jews were by nature like other nations, so that their different condition did not proceed from themselves, or from their own worthiness, but from the gratuitous love of God. ${ }^{5}$

However, they had shaken off the yoke, and having despised God had given themselves up again to many corruptions. In short, the Jews paid him no reverence, he complains that he was defrauded of his right as a father; and as they entertained no fear for him. ${ }^{6}$

God could reply the Jews hardly because $\mathrm{He}$ created them and $\mathrm{He}$ is their father who gave them foods. He is the one who gives sun to shine every day for them and fruits in the land which bears its fruits even $\mathrm{He}$ bounds them with so many graces and goodness for them. He also adopted them to be His children through Abraham's seed.

Though, they still questioned His love and kept living in sins. ${ }^{7}$ Hence, there are two sins which Israel kept doing at that time.

\footnotetext{
${ }^{5}$ http://www.ccel.org/ccel/calvin/calcom30.pdf ${ }^{6}$ http://www.magister.msk.ru/library/bible/comment /calvin/calvin17.htm ${ }^{7}$ Ibid.
}

Firstly, they were forgetting God's kindness into their life and, secondly, they kept living in their sins which He rebuked in the book of Malachi. ${ }^{8}$

Despite of their wickedness, Calvin is amazed with God's election which has a lot of favor. He chooses Jacob (Israel) over their forgetfulness about His love and their iniquities $\mathrm{He}$ elects Jacob beyond Esau status as a firstborn and also his birthright. Esau should get his birthright because he is the oldest brother, but because of God has predestined Jacob from eternity that he is refused (Gen. 25:23). ${ }^{9}$

God chooses them to be His people not because of their merit or goodness but His great love only. Deuteronomy 9:6 also restates that God elects Israel among other nations not because of their righteousness but because He knows since the beginning that Israel is rebel, stubborn and stiffnecked people. In the context of Malachi, Calvin concluded that Jacob's election and Esau's rejection are because God's own will not because of human merit. This is a double predestination teaching. ${ }^{10}$ Also, Voluntarism role is prominent in Calvin's interpretation who says that human cannot

\footnotetext{
${ }^{8}$ John Calvin, Calvin: Commentaries (Grand Rapids, MI: Christian Classics Ethereal Library, 1958), 199202.

${ }^{9}$ Ibid.

${ }^{10} \mathrm{http} / /$ www.iclnet.org/pub/resources/text/m.sion/c vmal-01.htm
} 
satisfy God. Therefore, if man is elected or rejected it because God's will only.

In the New Testament, Calvin took reference from Roman 9:11-22 $2^{11}$ as the basis for his double predestination doctrine. In those verses, Apostle Paul explains so clearly that there are two type of man. The first type is man who is predestined to be loved and the second one is the man who is predestined to be destroyed (Rom. 9:22). Calvin said that Paul now begins to ascend higher (verse 11), even to show the cause of this difference, which he teaches us is nowhere else to be found except in the election of God.

He had indeed before briefly noticed, that there was a difference between the natural children of Abraham, that though all were adopted by circumcision into a participation of the covenant, yet the grace of God was not effectual in them all; and hence that they, who enjoy the favor of God, are the children of the promise. But how it thus happened, he has been either silent or has obscurely hinted. Now indeed he openly

\footnotetext{
${ }^{11}$ For the Scriptures said to Pharaoh, "This is why I raised you up, that I may show my power in you, and that my name may be made known in all the earth." So he has mercy on whom he wills and hardens the hearts of whom he wills. Now you will say to me, "If So, what else is he still blaming? For who is against his will?" Who are you, man, that you oppose God? Can the formed say to the one who formed it, "Why have you formed me like this?" Does the potter have no right to his clay, to make from lumps? the same thing to be used for a noble purpose and another
}

ascribes the whole cause to the election of God, and that gratuitous, and in no way depending on men; so that in the salvation of the godly nothing higher (nihil superius) must be sought than the goodness of God, and nothing higher in the perdition of the reprobate than his just severity. ${ }^{12}$

Then the first proposition is, "as the blessing of the covenant separates the Israelitic nation from all other people, so the election of God makes a distinction between men in that nation, while he predestinates some to salvation, and others to eternal condemnation."13 The second proposition is, "There is no other basis for this election than the goodness of God alone, and also since the fall of Adam, his mercy; which embraces whom he pleases, without any regard whatever to their works." 14 The third is, "The Lord in his gratuitous election is free and exempt from the necessity of imparting equally the same grace to all; but, on the contrary, he passes by whom he wills, and whom he wills he chooses." 15

\footnotetext{
thing to be used for ordinary purposes? So, when it comes to showing His wrath and manifesting His power, God has great patience with the objects of His wrath, which have prepared for destruction.

12 John Calvin, Commentary on Romans (Grand Rapids, MI: Christian Classics Ethereal Library), 302-303.

${ }^{13}$ Ibid.

${ }^{14}$ Ibid

${ }^{15}$ Ibid., 304.
} 
All these things Paul briefly includes in one sentence: he then goes on to other things. Moreover, by these words, when the children had not yet been born, nor had done any good or evil, he shows that God in making a difference could not have had any regard to works, for they were not yet done. Now they who argue on the other side, and say, that this is no reason why the election of God should not make a difference between men according to the merits of works, for God foresees who those are who by future works would be worthy or unworthy of his grace, are not more clearsighted than Paul, but stumble at a principle in theology, which ought to be well known to all Christians, namely, that God can see nothing in the corrupt nature of man, such as was in Esau and Jacob, to induce him to manifest his favor. ${ }^{16}$ When therefore he says, that neither of them had then done any good or evil, what he took as granted must also be added that they were both the

\footnotetext{
${ }^{16} \mathrm{http}: / /$ www.ccel.org/ccel/calvin/calcom38

17 Archbishop Usher asks this question, "Did God, before he made man, determine to save some and reject others?" To this he gives this answer, _ "Yes, surely; before they had done either good or evil, God in his eternal counsel set them apart." It is the same sentiment that is announced here by Calvin But to deduce it from what is said of Jacob and Esau, does not seem legitimate, inasmuch as they were in a fallen condition by nature, and the reference is evidently made to anything done personally by themselves. Election and reprobation most clearly presuppose man as fallen and lost: it is hence indeed, that the words derive their meaning. That it was
}

children of Adam, by nature sinful, and endued with no particle of righteousness.

It may further be said, that though that corruption alone, which is diffused through the whole race of man, is sufficient, before it breaks out, as they say, into action, for condemnation, and hence it follows, that Esau was justly rejected, for he was naturally a child of wrath, it was yet necessary, lest any doubt should remain, as though his condition became worse through any vice or fault, that sins no less than virtues should be excluded.

It is indeed true, that the proximate cause of reprobation is the curse we all inherit from Adam; yet, that we may learn to acquiesce in the bare and simple good pleasure of God, Paul withdraws us from this view, until he has established this doctrine, — That God has a sufficiently just reason for electing and for reprobating, in his own will. ${ }^{17}$ According to the purpose of God's election, Paul speaks of the

God's eternal purpose to choose some of man's fallen race, and to leave others to perish, is clearly taught us: but this is a different question from the one touched upon here, - that this purpose was irrespective of man's fall, - a sentiment which, as far as I can see, is not recognised nor taught in Scripture. And not only Calvin, but many other divines, both before and after him, seem to have gone in this respect somewhat beyond the limits of revelation; it is true, by a process of reasoning apparently obvious; but when we begin to reason on this high and mysterious subject, we become soon bewildered and lost in mazes of difficulties. 
gratuitous election of God almost in every instance. If works had any place, he ought to have said, "That his reward might stand through works;" but he mentions the purpose of God, which is included, so to speak, in his own good pleasure alone.

That no ground of dispute might remain on the subject, he has removed all doubt by adding another clause according to election, and then a third, not through works, but through him who calls. Since the purpose of God according to election is established in this way that before the brothers were born, and had done either good or evil, one was rejected and the other chosen; it hence follows, that when any one ascribes the cause of the difference to their works, he thereby subverts the purpose of God. ${ }^{18}$ Now, by adding, not through works,

\footnotetext{
${ }^{18} \mathrm{http} / / / \mathrm{www} . c c e l . o r g / \mathrm{ccel} / \mathrm{calvin} / \mathrm{calcom} 38$

19 Nothing can be conceived more conclusive in argument than what is contained here. The idea of Foreseen works, as the reason or the ground of election, is wholly excluded. The choice is expressly denied to be on account of any works, and is as expressly ascribed to the sovereign will of God. "He does not oppose works to faith, but to him who calls, or to the calling, which precedes faith, that is, to that calling which is according to God's purpose. Paul means, that the difference between Jacob and Esau was made through the sole will and pleasure of God, not through their wills or works, existing or foreseen." - Poli. Syn. Yet some of the Fathers, as Chrysostom and Theodoret, as well as some modern divines, ascribe election to foreseen works. How this is reconcilable with the argument of the Apostle, and with the instances he adduces, it is indeed a very hard matter to see. One way by which the Apostle's argument is evaded, is, that the election here is to temporal and outward privileges. Be it so: let this be
}

but through him who calls, he means, not on account of works, but of the calling only; for he wishes to exclude works altogether. We have then the whole stability of our election inclosed in the purpose of God alone: here merits avail nothing, as they issue in nothing but death; no worthiness is regarded, for there is none; but the goodness of God reigns alone. False then is the dogma, and contrary to God's word that God elects or rejects, as he foresees each to be worthy or unworthy of his favor. ${ }^{19}$

\section{In Institutio Book}

Despite of his work in Institutio had been revised but his double predestination doctrine doesn't change at all

granted; but it is adduced by the Apostle as an illustration - and of what? most clearly of spiritual and eternal election. He refers both to the same principle, to the free choice of God, and not to anything in man. "God foresaw the disposition of each." - Theodoret and Chrysostom "His election corresponds with the foreseen disposition of men." - Theodoret "It was done by the prescience of God, whereby he knew while yet unborn, what each would be." - Augustine These are quotations made by a modern writer (Bosanquet)with approbation: but surely nothing could be suggested more directly contrary to the statements and the argument of the Apostle. There is a mistake, I apprehend, as to the last quotation; perhaps similar to that made in quoting Augustine on the latter part of the 7 th chapter of this Epistle, where the writer quotes a sentiment of Augustine, which he afterwards retracted, a thing which has been often done by the advocates of Popery, but by no means becoming a Protestant. 
fundamentally in twenty three years since the first until the last Latin edition. He kept teaching this doctrine assertively. ${ }^{20}$ In his book "Institutio", especially chapter 21 and 22, Calvin gave a question how can someone explain why not all people listen Gospel? According to Calvin, the answer is based on God's election in eternity in which He has predestined some people to be saved and others to be perished. ${ }^{21}$

Calvin also stated that God gives faith only to the elects. It is because of his decision since the beginning because he knows all of his works beforehand (Acts. $15: 18$ ), and all things have been worked by his decision (Ep. 1:11). ${ }^{22}$ Based on God's decision, the hearts of the elects are softened with his mercy and subdued to believe though their hearts were hard. In contrast, based on God's same decision, the others are left in their sins and hardened heart with God's punishment. This diversity is the top of divine judgement and His mercy. ${ }^{23}$ Therefore, Calvin's doctrine is not only explaining why only some people come to God through faith but the others are not.

Calvin opposed God's election based on foreknowledge of merit (praescientiam

\footnotetext{
${ }^{20}$ Michael S. Horton, Institutes Calvin (Jakarta: Momentum, 2009), 115.

${ }^{21}$ John Calvin, Institute of Christian Religions, 566.

${ }^{22}$ Ibid.
}

faciunt eius causam). The question considered is the origin and cause of election. The advocates of foreknowledge insist that it is to be found in the virtues and vices of men. For they take the short and easy method of asserting, that God showed in the person of Jacob, that he elects those who are worthy of his grace; and in the person of Esau, that he rejects those whom he foresees to be unworthy.

Such is their confident assertion; but what does Paul say? "For the children being not yet born, neither having done any good or evil that the purpose of God according to election might stand, not of works, but of him that calleth; it was said unto her, [Rebecca,] the elder shall serve the younger. As it is written, Jacob have I loved, but Esau have I hated," (Rom. 9:11-13). ${ }^{24}$ If foreknowledge had anything to do with this distinction of the brothers, the mention of time would have been out of place. Granting that Jacob was elected for a worth to be obtained by future virtues, to what end did Paul say that he was not yet born? Nor would there have been any occasion for adding, that as yet he had done no good, because the answer was always ready, that

\footnotetext{
${ }^{23}$ Van Den End, Enam Belas Dokumen Dasar Calvinisme (Jakarta: BPK Gunung Mulia, 2001), 59. ${ }^{24}$ http://siratemustaqeem.com/web/uBooks/Christianity\%20Boo ks/Philosophers\%20and\%20Theologians/Calvin\%2 OInstitutes\%20of\%20Christian\%20Religion.pdf
} 
nothing is hid from God, and that therefore the piety of Jacob was present before him. If works procure favor, a value ought to have been put upon them before Jacob was born, just as if he had been of full age. But in explaining the difficulty, the Apostle goes on to show, that the adoption of Jacob proceeded not on works but on the calling of God..$^{25}$

In works he makes no mention of past or future, but distinctly opposes them to the calling of God, intimating, that when place is given to the one the other is overthrown; as if he had said, The only thing to be considered is what pleased God, not what men furnished of themselves. Lastly, it is certain that all the causes which men are wont to devise as external to the secret counsel of God, are excluded by the use of the terms purpose and election. ${ }^{26}$ In short, some people are determined to have eternal life and the others are predestined to have eternal death. This decree can't be violated (inviolabilis manet). Therefore, Calvin thought that predestination which based on

\footnotetext{
25 Ibid.

${ }^{26}$ The salvation of believers is founded entirely on the decree of divine election, that the privilege is procured not by works but free calling. We have also a specimen of the thing itself set before us. Esau and Jacob are brothers, begotten of the same parents, within the same womb, not yet born. In them all things are equal, and yet the judgment of God with regard to them is different. He adopts the one and rejects the other. The only right of precedence was that of primogeniture; but that is disregarded, and the
}

foreknowledge is not an act of God which is free based on his free will. This kind of predestination limits God's will because it is based on His foreknowledge to his creations. Calvin thinks that it cannot be happen. ${ }^{27}$ In conclusion, Calvin defines predestination as God's perpetual decree which $\mathrm{He}$ has predestined before what $\mathrm{He}$ wants to do for everyone not because of His foreknowledge.

There are some people who think that if God's election based on his will only not his foreknowledge, then predestination for those who are not can be said that it is unfair. However, Calvin argued that God doesn't owe anything to man. It means all man in this world are deserved to be punished because all of them have fallen into sins. If God chooses some people to be saved, God is not fair but it because of His love. He doesn't need to save all people because all man should be perished. If God predestines some people to be perished, it is not contradicted with his justice because all mean should be punished. ${ }^{28}$

younger is preferred to the elder. Nay, in the case of others, God seems to have disregarded primogeniture for the express purpose of excluding the flesh from all ground of boasting. Rejecting Ishmael he gives his favor to Isaac, postponing Manasseh he honors Ephraim.

${ }^{27}$ John Calvin, Institute of Christian Religions, 575577.

${ }^{28}$ Ibid., 583-586. 
Therefore, Calvin concluded that double predestination doctrine is very important teaching to defend God's nature both His love and His justice. ${ }^{29}$ It means if God chooses to save all people who are sinners, he is unjustice God because no punishment at all for sinners. However, if he punishes all man then His love will be questioned. In addition, Calvin also adduced that God's justice is beyond man's capacity to question it. He used verses in Romans 9:21-23 to defend God's sovereignity in predestination both people who are saved and those who are perished. In summary, double predestination doctrine is the best solution to defend God's love, justice and sovereignity.

The benefit of predestination is the special election which otherwise would remain hidden in God, he at length manifests by his calling. "For whom he did foreknow, he also did predestinate to be conformed to the image of his Son." Moreover, "whom he did predestinate, them he also called; and whom he called, them he also justified," that he may one day glorify (Rom. 8:29, 30). ${ }^{30}$ Though the Lord, by electing his people, adopted them as his sons, we, however, see that they do not come into possession of this great good until they are called; but when called, the enjoyment of their election is in some measure communicated to them. Because Holy Spirit dwells into their hearts and Paul uses the terms "Spirit of adoption," and the "seal" and "earnest" of the future inheritance; because by his testimony he confirms and seals the certainty of future adoption on their hearts. Therefore, the benefit of predestination doctrine is not only offers salvation but also God has determined (assignat) salvation so that gives assurance for believers. ${ }^{31}$ In addition, Calvin also describes that people who refuse this doctrine are those who don't want to be controlled by God's words and they eliminate a basis for Christian assurance (solidae fiduciae). ${ }^{32}$ In conclusion, Calvin thinks that predestination doctrine is the best doctrine for Christian faith.

\section{REFERENCES}

[1] Calvin, John. Commentaries. Grand Rapids, MI: Christian Classics Ethereal Library. 1958. Commentary on Romans.

Grand Rapids, MI: Christian Classics Ethereal Library. 1958

\footnotetext{
${ }^{29}$ Ibid., 588-590.

${ }^{31}$ Ibid., 670-671.

${ }^{30}$ Ibid.

${ }^{32}$ Ibid., 673-674.
} 
[3] , Institute of Christian

Religions. Grand Rapids, MI: Christian

Classics Ethereal Library. 1958

[4] Commentaries on the

Epistle of Jude. Grand Rapids, Michigan:

Baker Book House, reprinted 1984.

[5] Chia, P. S., \& Juanda, J. (2020).

Penafsiran Amilenialisme \& Teologi

Kovenan Dalam Memahami Alkitab.

Journal Kerusso, 5(2), 1-23.

[6]End,Vanand.EnamBelasDokumenDasar

Calvinisme. Jakarta: BPK GunungMulia, 2001.

[7] Horton,S Michael.Institutes Calvin (Jakarta: Momentum, 2009.

[8]Http://www.ccel.org/ccel/calvin/calcom30.pdf

[9]Http://www.ccel.org/ccel/calvin/calcom30.pdf

[10]Http://www.magister.msk.ru/library/bible/

comment/calvin/calvin17.htm

[11]Http://www.iclnet.org/pub/resources/text/

m.sion/cvmal-01.htm

[12]Http://www.ccel.org/ccel/calvin/calcom38

[13]Http://www.ccel.org/ccel/calvin/calcom38

[14]Http://www.ccel.org/ccel/calvin/calcom38

[15]Http://www.iclnet.org/pub/resources/text/

m.sion/cvmal-01.htm

[16]Http://www.ccel.org/ccel/calvin/calcom38.pdf

[17]Http://www.biblestudyguide.org/comm

ent/calvin/comm_vol45/htm/iv.iii.ii.htm

[18]Http://www.ccel.org/ccel/calvin/calco

m45.iv.iii.i.html
[19]Http://www.biblestudyguide.org/comm ent/calvin/comm_vol45/htm/viii.iii.htm [20]Http://siratmustaqeem.com/web/uBook s/Christianity\%20Books/Philosophers\%20 and\%20Theologians/Calvin\%20Institutes \%20of\%20Christian\%20Religion.pdf

[21] Kistemaker, Simon J.New Testament Commentary: Exposition of the Epistles of [22] Peter and of the Epistle of Jude. England: Evangelical Press, 1987.

[23] Poole,Mattew.A Commentary on the Holy Bible. Mclean, Virginia: MacDonald Publishing House, 1986.

[24] Michael S. Horton, Institutes Calvin (Jakarta: Momentum, 2009. 